\title{
A MARINE CONNECTION BETWEEN PARNAIIBA AND PARANÁ BASINS DURING THE EIFELIAN/GIVETIAN TRANSITION: REVIEW AND NEW DATA
}

\author{
YNGVE GRAHN \\ Calle Azucena 10,29680, Estepona, Spain.yngvegrahn@gmail.com
}

RODRIGO SCALISE HORODYSKI

Programa de Pós-Graduação em Geologia, UNISINOS, Avenida Unisinos, Cristo Rei, 84010500,

São Leopoldo, RS, Brazil.rshorodyski@gmail.com

PAULA MENDLOWICZ MAULLER

Rua Araújo Lima 24/304, Vila Isabel, 20541-050, Rio de Janeiro, R.J., Brazil.mendlowicz@gmail.com

\section{ELVIO P. BOSETTI}

Departamento de Geociências, Universidade Estadual de Ponta Grossa, Av. Carlos Cavalcanti 9.500, Uvaranas, 84010-919 Ponta Grossa, PR, Brazil.elvio.bosetti@pq.cnpq.br

RENATO P. GHILARDI

Departamento de Ciências Biológicas, Faculdade de Ciências de Bauru, UNESP, Av. Eng. Luiz Edmundo Carrijo Coube 14-01, 17033-360, Bauru, SP, Brazil. ghilardi@fc.unesp.br

FABIO A. CARBONARO

Programa de Pós-Graduação em Biologia Comparada, Faculdade de Filosofia, Ciências e Letras de Ribeirão Preto, USP, Av. Bandeirantes, 3900, Ribeirão Preto, SP, Brazil.fabiocarbonaro@yahoo.com.br

\begin{abstract}
A long-lived marine seaway between the Parnaíba and Paraná basins occurred during a global marine transgression between Brazilian intracratonic basins (except for the Solimões Basin) in the latest Eifelian/earliest Givetian (Middle Devonian). As a result of this transgression a catastrophic event (KAČÁK) in combination with the immigration of warm water Appalachian and Old World faunas contributed to the collapse of the Malvinokaffric Realm in the Paraná Basin. In the Alto Garças and Apucarana sub-basins, the transgression is notable in the early Givetian with an impoverished shelly fauna following the KAČ́AK post-extinction event in the earliest Givetian.
\end{abstract}

Key words: Parnaíba Basin, Paraná Basin, seaway, taphonomic bias, early Givetian, Malvinokaffric Realm.

RESUMO - Uma conexão marinha duradoura entre as bacias do Parnaíba e do Paraná ocorreu durante uma transgressão marinha global entre bacias intracratônicas brasileiras (exceto a Bacia do Solimões) no final do Eifeliano/início do Givetiano (Devoniano Médio). Em consequência desta transgressão, um evento catastrófico (KAČÁK), em combinação com a imigração de água morna Appalachiana e faunas do Velho Mundo, contribuíram ao colapso do Reino Malvinokáffrico na Bacia de Paraná. Nas sub-bacias de Alto Garças e Apucarana, a transgressão é notável no Givetiano inferior, com uma fauna empobrecida de conchas após o evento de pós-extinção de KAČÁK no início do Givetiano.

Palavras-chave: Bacia do Parnaíba, Bacia do Paraná, via marítima, tendenciamento tafonômico, Givetiano inferior, Reino Malvinokáffrico.

$\dagger$ Dedicated to the memory of late Dr. Gordon D. Wood, an American palynologist and friend who passed away prematurely. 


\section{INTRODUCTION}

Previously the nature of marine connections between the intracratonic basins of Brazil was insufficiently known. More recent and precise palynological dating has made it possible to reconstruct the Devonian paleogeography of the Brazilian intracratonic basins (Melo \& Loboziak, 2003; Grahn \& Melo, 2003, 2005; Grahn et al., 2005, 2006, 2010a,b, 2013; Breuer \& Grahn, 2011). Based on these data the connections between the basins can be studied in more detail (Figure 1A). Melo (1988) discussed possible Early Devonian connections between the Paraná and Parnaíba basins. In the 1980's the precise ages of the Jaicós (Parnaíba Basin) and Furnas (Paraná Basin) formations was unknown. The lithology of the sandstones in the Graben Água Bonita (Figure 1A) were therefore compared to the lithologies of these two formations and considered as contemporaneous. Both the Jaicós and Furnas formations consist of mainly deltaic and shallow water sandstones. The upper part of the Furnas Formation has been dated as late Lochkovian (Rubinstein et al., 2005; Grahn et al., 2010a), while the uppermost Jaicós Formation is uppermost Pragian-lower Emsian (Grahn et al., 2005). The age relations between the Água Bonita Formation sandstones and those of the Paraná and Parnaíba basins are uncertain. As pointed out by Melo (1988), the lithologies of the Água Bonita sandstones have nothing in common with the sandstones in Chapada Group unit 3 (Paraná Basin; Grahn et al., 2010b). They are here considered as contemporaneous to the Furnas Formation/Chapada Group unit 1 in the Paraná Basin based on lithological criteria (Figure 2). Furthermore, uppermost Jaicós Formation is contemporary with the richly fossiliferous marine shales of the Ponta Grossa Formation sensu Oliveira (1912) (Grahn et al., 2013). The Paraná Basin had a deeper marine setting during the Early Devonian than the Parnaíba Basin. Based on a single find of the chitinozoan species Ramochitina $\mathrm{cf}$. $R$. magnifica, found $c a .1 \mathrm{~m}$ above the base of Chapada Group unit 2 south of Amorinópolis, the age was determined as latest Pragian-early Emsian for the lower Chapada Group unit 2 in that region (Grahn et al., 2000, 2010b). A more detailed investigation of the GO 1 section in this paper confirms the relative dating for the Chapada Group lower unit 2 below Chapada Group unit 3 (Figure 2). It therefore is likely that the base of Chapada Group unit 3 is late Emsian in age and corresponds to the Tibagi Member of the São Domingos Formation in the Apucarana Sub-basin (Grahn et al., 2013). The presence of a mainly deltaic/subtidal sandstone (Chapada Group unit 3) in the Alto Garças Subbasin during late Emsian-earliest Givetian, and deposition indicating a shallowing of the Parnaíba Basin towards the Paraná Basin during the late Emsian (Carozzi et al., 1975), would exclude a marine connection between the Parnaíba and Paraná basins during the late Emsian as discussed by Melo (1988). However, the Paraná Basin was connected with basins in the Andean (Bolivia) and Chaco (NW Argentina, Paraguay) regions during the Malvinokaffric Realm (e.g. Melo, 1988). A transgression affecting all the intracratonic basins of Brazil occurred during the late Eifelian to early Givetian and provided connections between the Amazonas, Parnaíba and Paraná basins. The peak of this transgression was probably related to the KAČÁK Event (House, 1996; Bosetti et al., 2011; Horodyski et al., 2014) in the Apucarana Sub-basin. In the northern Alto Garças Sub-basin the mainly deltaic/subtidal sandstones of Chapada Group unit 3 were flooded during earliest Givetian (Figure 2). The classical Malvinokaffric shelly fauna disappears in the earliest Givetian (Bosetti et al., 2011), and Appalachian and Old World faunas expand into the former Malvinokaffric Realm. However, the response in the Paraná Basin is an impoverished shelly fauna after the collapse of the classical Malvinokaffric fauna in the earliest Givetian. The Caiapônia (GO 15) and Caiapônia-Doverlândia (GO 16) sections (Figures 1B, 4) described below are situated above the Chapada Group 3 and dates the transgression into the Paraná Basin as Middle Devonian. The Doverlândia locality (GO 18, Figures 1B, 4) has not been investigated for palynomorphs in this study, but a shelly fauna is present (see below).

\section{MATERIAL AND METHODS}

\section{Repositories of the studied fossil material}

The trilobites described by Carvalho et al. (1987) from locality GO 15 (= Ribeirão do Monte) are stored at Museu Nacional, Universidade Federal do Rio de Janeiro (MN/UFRJ, registration numbers MN 6409-I, MN 6411-I, MN 6412-I, MN 6413-I, MN 6414-I), Rio de Janeiro, RJ, Brazil (transferred from the fossil collections at CENPES, Petrobras, Rio de Janeiro), and other macrofossils discussed from GO 1, 16 and 18 at Coleção Cíentifica a do Laboratório de Paleontologia de Macroinvertebrados (CCLP), Universidade Estadual Paulista (UNESP), Bauru, SP, Brazil. Palynological slides are stored at Laboratório de Estratigrafia e Paleontologia, Departamento de Geociências, Universidade Estadual de Ponta Grossa (UEPG), Ponta Grossa, PR, Brazil.

\section{Studied localities}

Four critical localities (Figures 1B, 3-4) for the understanding of the marine connections between the Parnaíba and Paraná basins have been investigated. They are described below.

Amorinópolis Section, GO 1 (51'5’34,058”W, 16³6'1,643”S). The Amorinópolis section (Figures 1B, 3) is critical for reconstructing marine connections between the Parnaíba and Paraná basins. It is situated along the Transbrazilian lineament (Cordani et al., 1984) in the Alto Garças Subbasin. The locality is a road-cut along GO-174 south of Iporá city. The lithologies consists of $c a .4 \mathrm{~m}$ bioturbated siltstones (Figure 3) with a rich palynomorph assemblage including the spores Brochotriletes foveolatus Naumova, 1953, Dictyotriletes emsiensis (Allen) McGregor, 1973, Emphanisporites mcgregorii Cramer, 1966, Emphanisporites rotatus McGregor, 1961, cf. Knoxisporites riondae Cramer \& Díez, 1975, Perotrilites caperatus (McGregor) Steemans, 


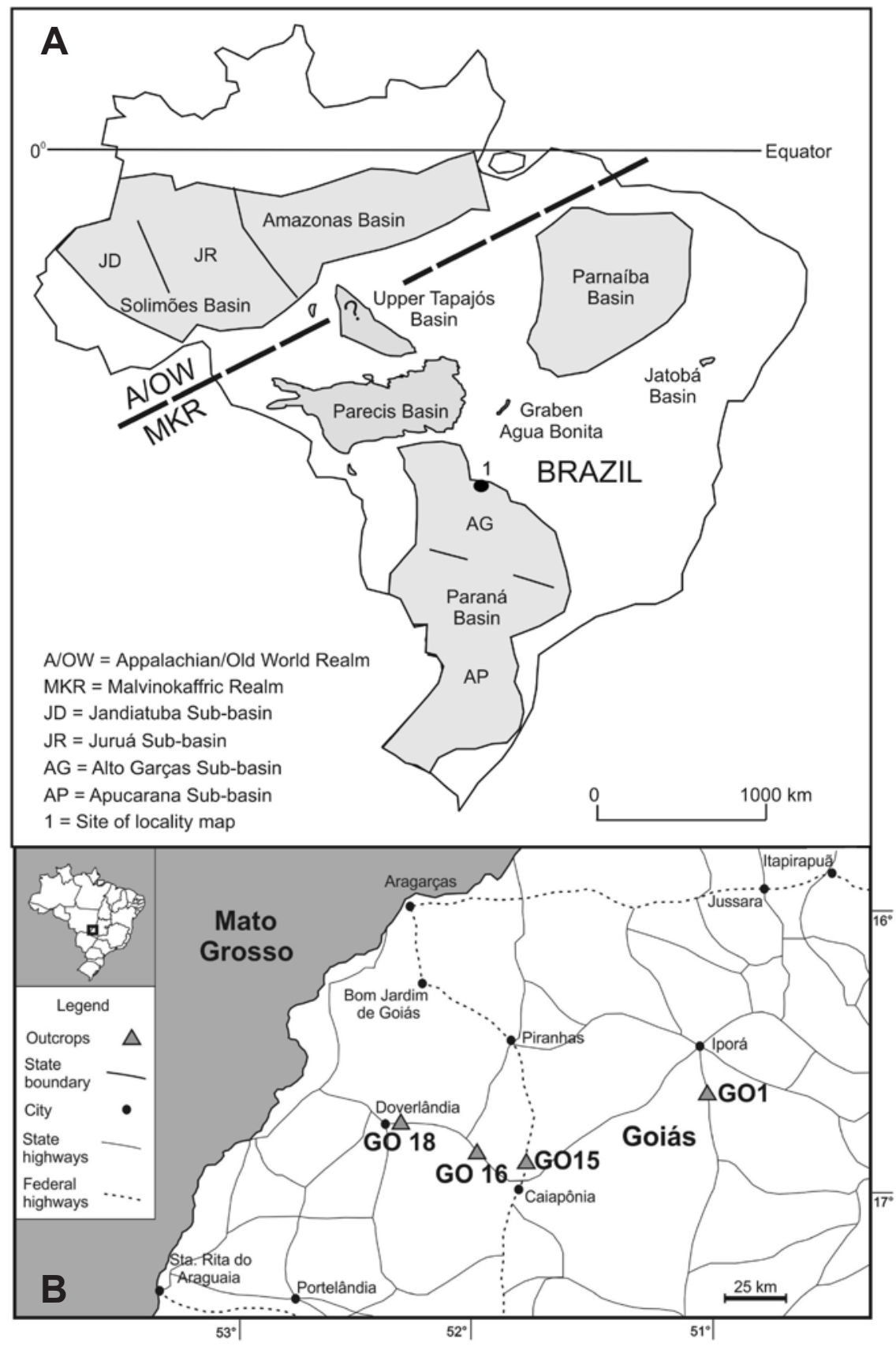

Figure 1. A, map showing the Devonian intracratonic basins of Brazil. B, detailed map of localities discussed in the text. Abbreviations: GO 1, Amorinópolis Section; GO 15, Caiapônia Section; Go 16, Caiapônia-Doverlândia Section; Go 18, Doverlândia Section.

1989 and Retusotriletes sp., and the acritarchs Bimerga paulae Le Hérissé, 2011, Quadrisporites variabilis (Cramer, 1966) Jardine et al., 1971 and Triangulina alargada Cramer, 1964 (Figure 5). Known macrofossils are restricted to ichnofossils (Carbonaro \& Ghilardi, 2016). The palynomorphs indicate the lower Chapada Group 2 (Grahn et al., 2010b) and a latest Pragian-early Emsian age (PoW Su spore Zone).

Caiapônia Section, GO 15 (5146’48.022”W, 1650'40,059”S). The Caiapônia section is a road-cut along BR-158 northeast of Caiapônia city (Figures 1B, 4). The lithologies consists of ca. $2.7 \mathrm{~m}$ shales and siltstones with an interbedded sandstone.
A poor palynomorph assemblage was found in two samples. The acritarch species Duvernaysphaera angelae Deunff, 1964 and the chitinozoan species Alpenachitina eisenacki Dunn \& Miller, 1964, ?Ancyrochitina flexuosa Burjack, 1996, and Eisenackitina aranea Urban, 1972 (Figure 6) occur. The fossils indicate the lower Chapada Group 4 (Grahn et al., 2010b) and an early Givetian age. Daemon in Andrade \& Camarço (1978) dated the lower part of Chapada Group 4 with spores as Givetian s.l. The shelly fauna (Figure 7) is discussed by Carbonaro \& Ghilardi (2016) and includes the brachiopods Orbiculoidea baini (Sharpe, 1856), Orbiculoidea excentrica Lange, 1943, and Orbiculoidea sp., and the trilobites 


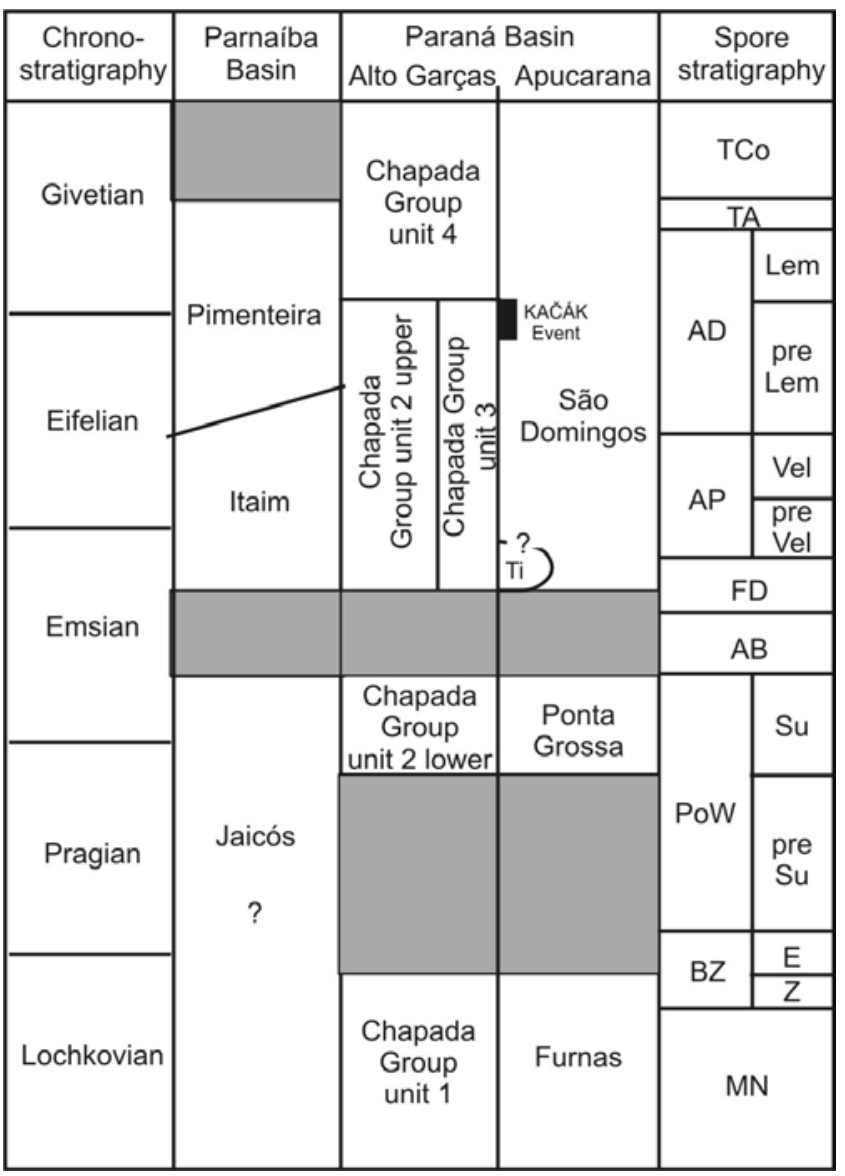

Figure 2. Correlations of Lower and Middle Devonian stratigraphy of the Parnaíba and Paraná basins. After Grahn et al. (2010b, 2013). Black bar indicates the stratigraphic extension of the KAČÁK Event.

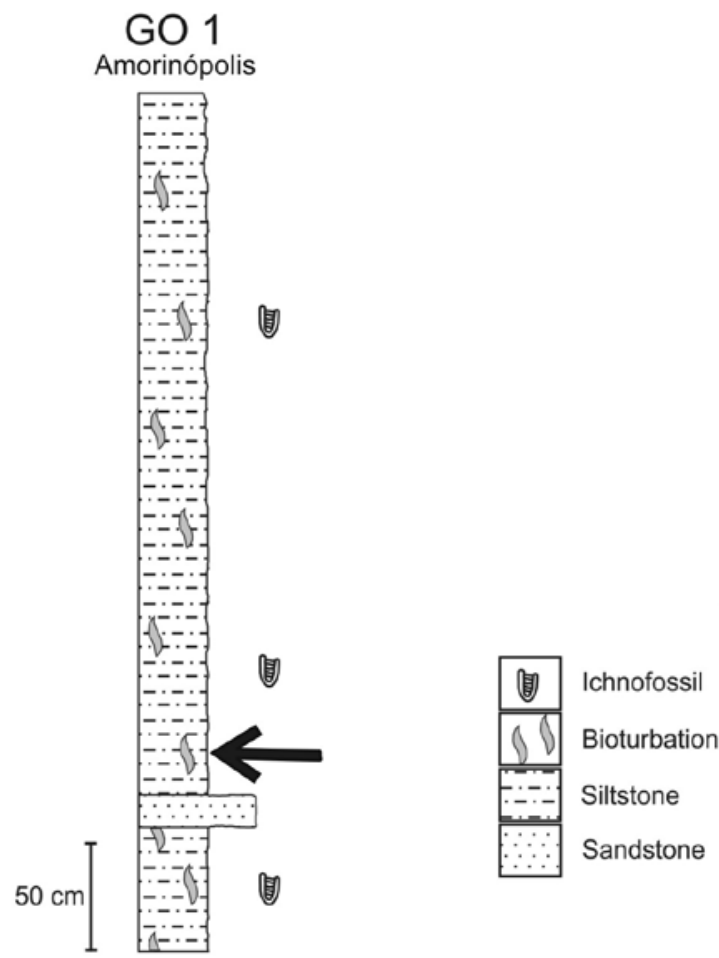

Figure 3. Stratigraphic column for locality GO 1 with sample level for palynomorphs (marked with an arrow).
Metacryphaeus cf. M. australis (Clarke, 1913), Metacryphaeus aff. M. australis, and Metacryphaeus sp. Carvalho et al. (1987) described the trilobites from GO 15 (the locality is also called Ribeirão do Monte).

Caiapônia-Doverlândia Section, GO 16 (5156'55.427’'W, $\left.16^{\circ} 48^{\prime} 51.620^{\prime \prime} \mathrm{S}\right)$.

The Caiapônia-Doverlândia Section is a road-cut along GO-221 northwest of Caiapônia city (Figures 1B, 4). The lithologies consists of $c a .7 \mathrm{~m}$ siltstone with an interbedded sandstone. A diagnostic palynomorph assemblage consisting of the acritarch species Chomotriletes vedugensis Naumova, 1953, Cymatiosphaera winderi (Deunff) Playford, 1977, Pterospermella reticulata Loeblich \& Wicander, 1976, Navifusa bacilla (Deunff) Playford, 1977, Duvernaysphaera angelae Deunff, 1964, Multipliscisphaeridium sp. and Muraticavea sp., and the spore species Grandispora sp., Samarisporites sp., and Cymbosporites cyathus Allen, 1965 (Figure 6) indicate the lower Chapada Group 4 (Grahn et al., 2010b) and an early Givetian age. This is same age as Daemon in Andrade \& Camarço (1978) have reported in the lower part of the Chapada Group 4. The macrofauna (Figure 7) include plant remains and the ichnofossil Bifungites sp. (Carbonaro \& Ghilardi, 2016).

Doverlândia Section, GO $18\left(52^{\circ} 15^{\prime} 46.897^{\prime}\right.$ 'W, $16^{\circ} 42^{\prime}$ 43.080"S).

The Doverlândia Section is a road-cut along GO-221 east of Doverlândia city (Figures 1B, 4). The lithologies consists of $c a .2 \mathrm{~m}$ siltstone with a shalebed at the top. The shales are uncomformably overlain by Carboniferous sandstones. A shelly fauna (Carbonaro \& Ghilardi, 2016) consisting of the trilobite Metacryphaeus tuberculatus (Kozlowski, 1923), the brachiopods Derbyina sp., Chonetidina indet., Obolidae indet., vestimentiferan tubes, and ichnofossils are present (Figure 7). The palynomorphs have not been investigated. However, no rocks younger than early Givetian have been encountered in this part of the Paraná Basin (Grahn et al., 2002, 2013).

\section{RESULTS AND DISCUSSION}

\section{Immigrant shelly faunas in the early Givetian}

In the earliest Givetian the shelly fauna in the Paraná Basin is mixed with immigrants and alien elements (Bosetti et al., 2011). At Casa de Pedra (Apucarana Sub-basin), the São Domingos Formation, stratigraphically above the KAČÁK post-extinction beds, yields an early Givetian warm water assemblage together with Malvinokaffric survivors (e.g. the trilobite Pennaia pauliana). The extraMalvinokaffric brachiopod Tropidoleptus carinatus entered the Paraná Basin during the early Givetian and marks the end of the Malvinokaffric Realm. T. carinatus migrated via the Amazonas and Parnaíba basins (Isaacson \& Perry, 1977; Isaacson, 1981; Melo, 1988; Fonseca \& Melo, 1987), more or less at the time of the Acadian orogeny, along with warm water counter-clockwise currents related to a transgression 


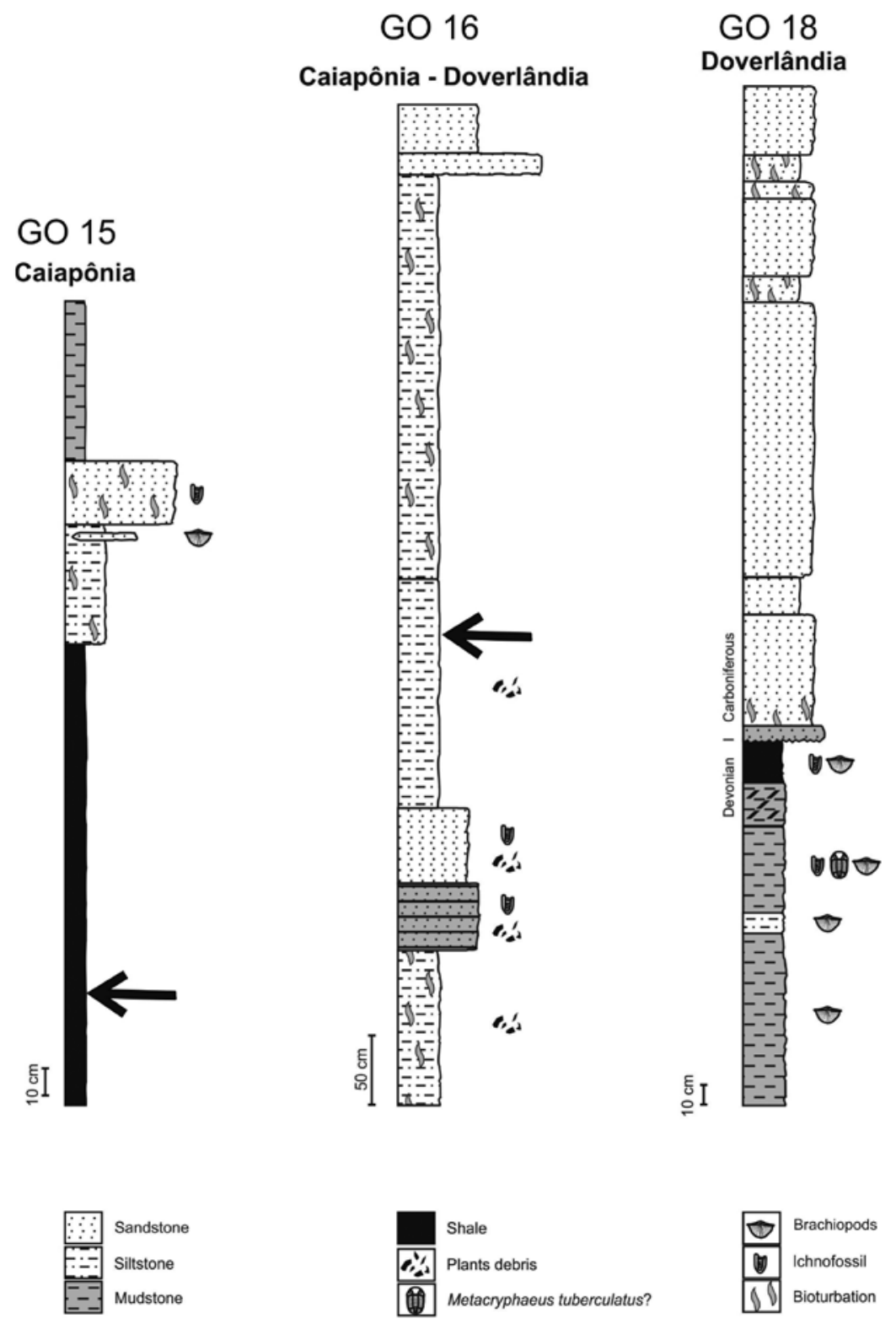

Figure 4. Stratigraphic columns for localities GO 15, 16, and 18 with sample levels of palynomorphs (marked with arrows).

and a drift of western Gondwana towards the north, allowing the passage of these warm currents (Barret \& Isaacson, 1988; Isaacson \& Sablock, 1990; Isaacson \& Díaz-Martínez, 1994; Isaacson, 1996, 2007; Scheffler et al., 2011). The trilobite Metacryphaeus tuberculatus is known from Eifelian to lower Famennian in the Parnaíba Basin (Castro, 1968; Lieberman, 1993, Lieberman et al., 1991), and from uppermost Pragian to lower Frasnian in Bolivia (Lieberman, 1993). It enters the Paraná Basin in the early Givetian after the collapse of the Malvinokaffric fauna. Crinoidea occur in the Paraná Basin at the base of the Givetian (e.g. Marettocrinus aff. $M$. sp. C, which occurs in the Lower Devonian of the Amazon Basin; Scheffler, 2010). Marettocrinus crinoids have been recorded in the initial layers of Givetian in the Paraná Basin by Ghilardi et al. (2011), Scheffler et al. (2011), Francisco \& Scheffler (2014), and Horodyski (2014), and in the Maecuru
Formation (Eifelian) of the Amazonas Basin by Scheffler (2010) and Scheffler et al. (2011). In addition, the occurrence of Salairocrinus? sp. was recorded by Francisco \& Scheffler (2014) from the lower Givetian in the Apucarana Sub-basin. Crinoids are not abundant. The specimens encountered are disarticulated and only represented by isolated columns or pluricolumns.

Enigmatic organisms fossilized in São Domingos Formation (post KAČÁK Event, lowermost Givetian, Paraná Basin, Horodyski et al., 2014) have been informally related to the orthoceratíd cephalopod ?Ctenoceras (Bosetti et al., 2011), or roll marks of coiled cephalopods or tentaculitiids (Bosetti et al., 2012; Horodyski et al., 2014). However, based on new finds an interpretation as Vestimentiferan worms was introduced by Bosetti et al. (2014). Another peculiarity of these fossils is that they frequently are associated with 

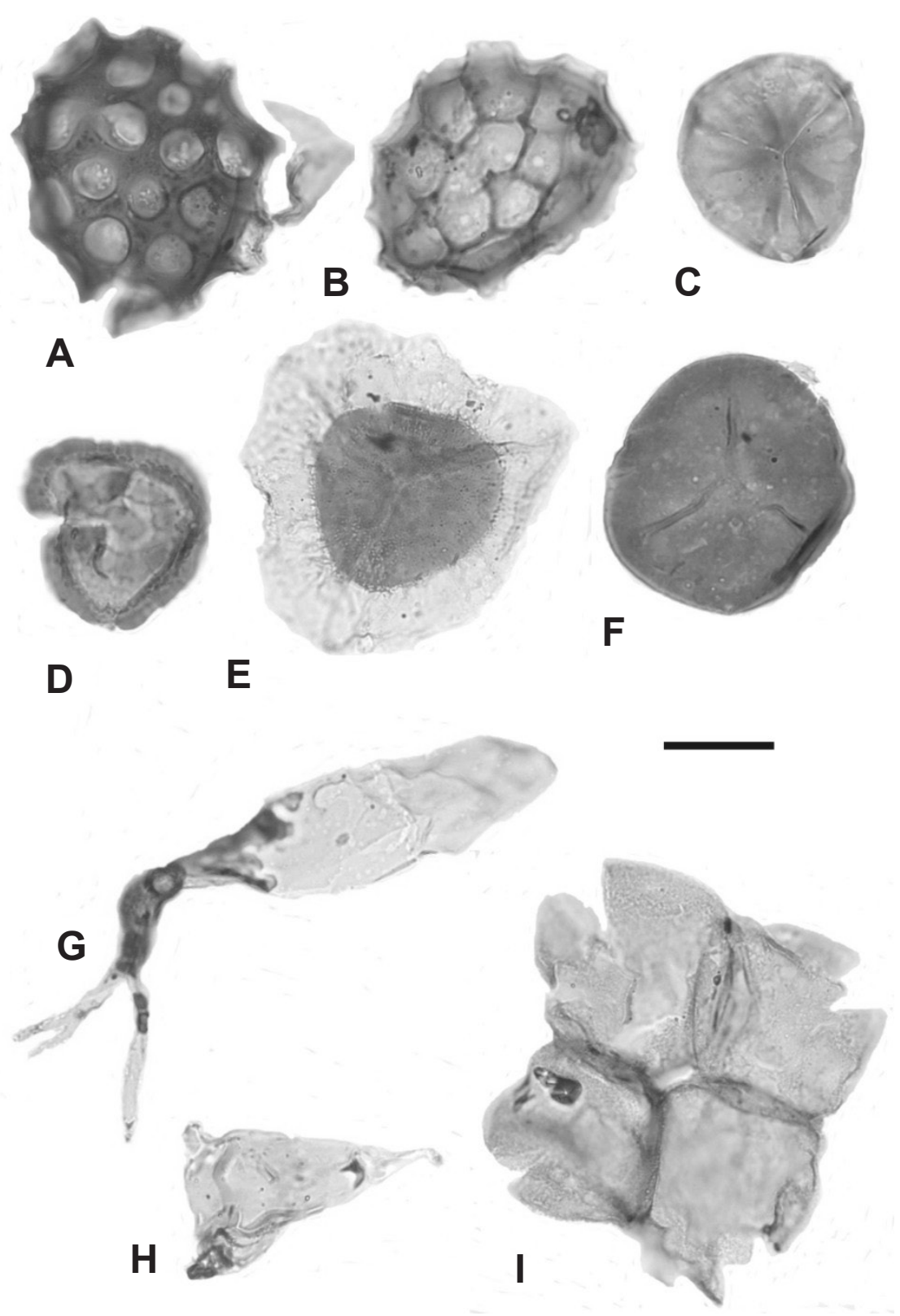

Figure 5. Selected uppermost Pragian-lower Emsian palynomorphs from locality GO 1. Chapada Group lower unit 2. A, Brochotriletes foveolatus Naumova 1953, H37/3. B, Dictyotriletes emsiensis (Allen) McGregor, 1973, H34/2. C, Emphanisporites mcgregorii Cramer, 1966, W42. D, cf. Knoxisporites riondae Cramer \& Díez, 1975, O34. E, Perotrilites caperatus (McGregor) Steemans, 1989, C35/2. F, Retusotriletes sp. O37. G, Bimerga paulae Le Hérissé, 2011, W42. H, Triangulina alargada Cramer 1964, V38/2. I, Quadrisporites variabilis (Cramer, 1966) Jardine et al., 1971, L37/3. Scale bar $=20$ um.

Phycosiphon isp (Horodyski et al., 2014). Both indicate a reducing environment. Phycosiphon can tolerate lower oxygen levels than any other ichnofossil (see Martin, 2004). It is usually the last ichnofossil to disappear in aerobic to anaerobic sedimentary sequences (Frey \& Seilacher, 1980). The occurrences in the Paraná Basin support the hypothesis of a stressed environment immediately following the great extinction during the KAČÁK Event.

\section{Taphonomic bias}

Horodyski (2014) tested the potential for preservation of fossils in the Ponta Grossa and São Domingos formations in a taphofacies study sensu Speyer \& Brett (1986, 1988). He demonstrated that the vast majority of taxa are stratigraphically positioned in Ponta Grossa Formation and the base of São Domingos Formation. These layers contain the climax of faunal biodiversity during latest Pragian-late Emsian in the Apucarana Sub-basin (Paraná Basin), which coincides with the Malvinokaffric Realm in Gondwana during the Early Devonian, previously established by Boucot (1971) and Melo (1988). The impoverishment of the fossils in the younger layers (Eifelian) may be a purely negative preservation-taphonomic attribute. The presence of shallower facies in the Eifelian, demonstrated by a 


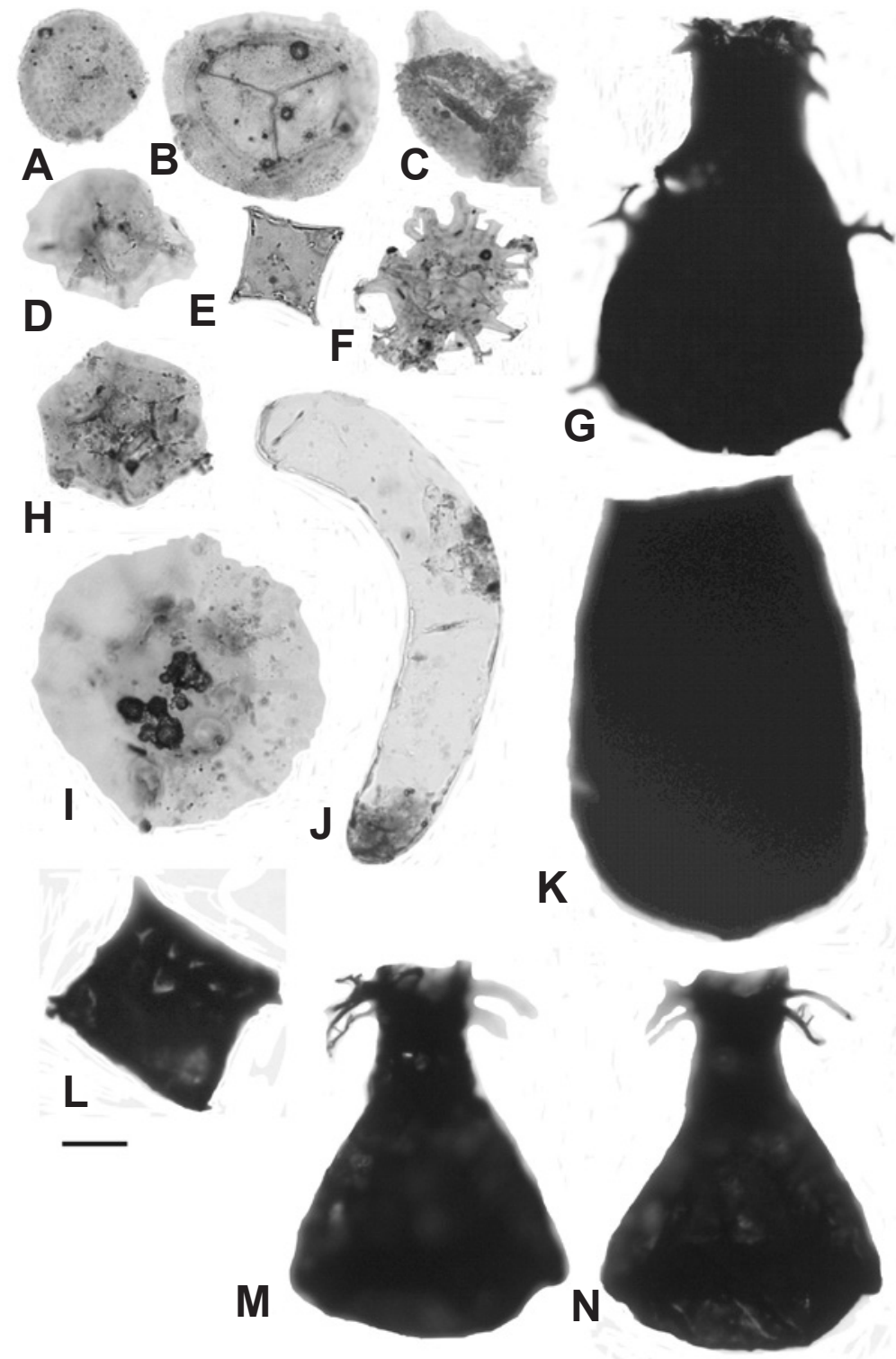

Figure 6. Selected palynomorphs from the lower Givetian at localities GO 15 and 16. Chapada Group lower unit 4. A, Cymbosporites cyathus Allen, 1965, GO 16, C39/4. B, Grandispora sp., GO 16, M45/3-4. C, Samarisporites sp., GO 16, O42/2-4. D, Cymatiosphaera winderi (Deunff) Playford, 1977, GO 16, U28/3-4. E, Duvernaysphaera angelae Deunff, 1964, GO 16, H39/1. F, Multiplisciphaeridium sp., GO 16, J45/2-4. G, Alpenachitina eisenacki Dunn \& Miller, 1964, GO 15A, Q39. H, Muraticavea sp., GO 16, F40/4. I, Pterospermella reticulata Loeblich \& Wicander, 1976, GO 16, A37. J, Navifusa bacilla (Deunff) Playford, 1977, GO 16, K40/1. K, Eisenackitina aranea Urban, 1972, GO 15B, P36. L, Duvernaysphaera angelae Deunff, 1964, GO 15A, C27. M-N, ?Ancyrochitina flexuosa Burjack, 1996, GO 15A, R43. M, Focus to the left. N, Focus to the right. Scale bar $=20$ um.

greater presence of bioturbated, hummocky cross-bedded sandstones and siltstones support this hypothesis. The taphonomically active zone (TAZ) was an important agent in destructing unique information, reworking all sediments with bioclasts by burrowers (e.g. necrophagous). In this process (Davies et al., 1989) dissolution of shells took place below the sediment-water interface (in the few millimeters of oxygenated sediment). Immediately above the "KAČ́Á" layers, the taphonomic preservation is excellent, with the presence of dwarfed relict Malvinokaffric invertebrates attributed to the "Lilliput Effect", a result of the KAČÁK post-extinction event (Bosetti et al., 2011; Horodyski et al.,
2014). Associated with these fossiliferous strata of earliest Givetian age occur crinoids, trilobites and ichnofossils presented in this study.

Given the above, ( $c f$. Horodyski, 2014), it becomes clear that positive taphonomic preservation conditions existed in the latest Pragian-late Emsian and early Givetian, and less so in the Eifelian. None of the immigrating taxa discussed here were recorded before Givetian in the Paraná Basin. We therefore assume that the shelly faunas after the KAČÁK Event are a result of migrations through marine connections between the Amazonas-Parnaíba-Paraná basins, as well as other regions of Gondwana and Laurentia. 


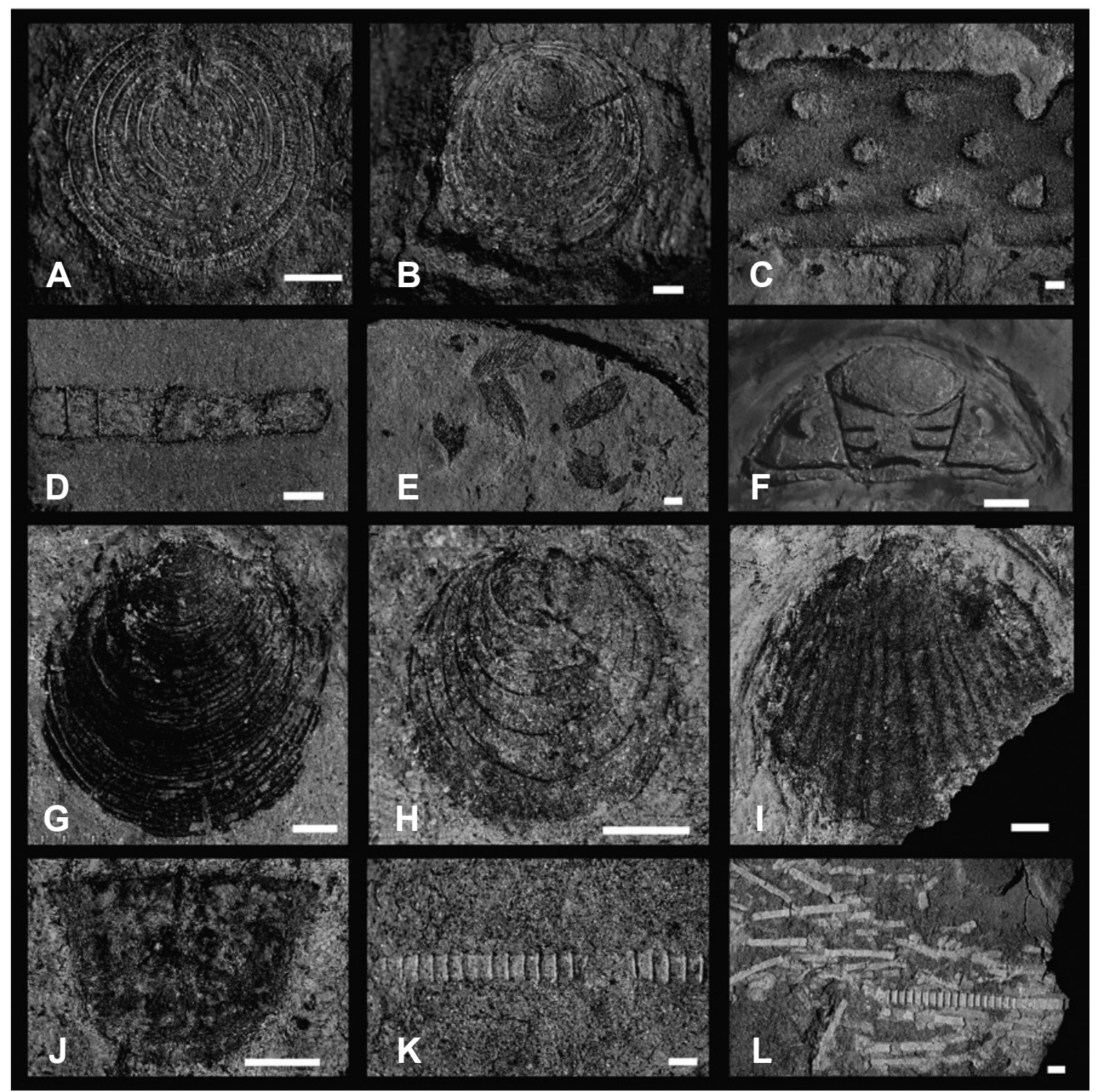

Figure 7. Selected macrofossils from the lower Givetian at localities GO 15 (A-C), 16 (D-E) and 18 (F-L). Chapada Group lower unit 4. A, mold of the ventral valve of Orbiculoidea baini Sharpe 1856 (CCLP 880). B, mold of the dorsal valve of Orbiculoidea excentrica Lange, 1943 (CCLP 876 ). C, Haplostigma sp. (CCLP 883). D-E, plant remains (CCLP 912 - 913). F, external mold of Metacryphaeus tuberculatus (Kozlowski, 1923) in dorsal view (CCLP 874a). G-H, dorsal valves of Obolidae indeterminate (CCLP 933, 936). I, dorsal valve of Derbyina sp. (CCLP 934). J, Chonetidina indeterminate (CCLP 935). K-L, probable vestimentiferan tubes (CCLP 939, 943). Scale bars: A-E, G, I, K-L = $1 \mathrm{~mm} ; \mathrm{F}=5 \mathrm{~mm}, \mathrm{H}, \mathrm{J}=0.5 \mathrm{~mm}$.

\section{CONCLUSION}

Marine connections between the Parnaíba and Paraná basins appear to have existed only from the Eifelian/Givetian transition onward. In the Paraná Basin, this transgression is probably associated with the KAČÁK Event, and were created by the global marine transgression at this time. During early Givetian warm water, Appalachian and Old World shelly faunas migrated into the former Malvinokaffric core area (Paraná Basin).

\section{ACKNOWLEDGEMENTS}

The first author thanks Group Palaios in Ponta Grossa for support of critical slides. R.S.H. thanks Coordenação de
Aperfeiçoamento de Pessoal de Nível Superior (CAPESPNPD) for financial support, S.M. Scheffler (Museu Nacional, Universidade Federal do Rio de Janeiro) and R.C. Marques (Museu de Zoologia, Universidade de São Paulo) for information and discussions. P.M.M. thanks L. Borghi and A.M. Rios Netto from IGEO/UFRJ, J.H.G. Melo and M.E. Longhim from CENPES/Petrobras for the possibility to study the palynological slides. E.P.B. thanks CNPq (CNPq 311483/2014-3) for financial support. R.P.G. and F.A.C. thanks FAPESP (2013/09683-3) for a grant and B.S. Francisco for help with the field works. Our sincere thanks to P. Isaacson (Moscow, Idaho) for checking the English. Two anonymous reviewers of an early draft of the manuscript are acknowledged. 


\section{REFERENCES}

Andrade, S.M. \& Camarço, P.E.N. 1978. Projeto Amorinópolis; mapeamento geológico a leste das cidades de Iporá-Amorinópolis. Goiânia, Nuclebrás/CENDOC, 32 p. (Internal report 2415/91).

Barrett, S.F. \& Isaacson, P.E. 1988. Devonian paleogeography of South America. In: N.J. McMillan; A.F. Embry \& D.J. Glass (eds.) Devonian of the world, Calgary, Canadian Society of Petroleum Geologists p. 655-667 (Memoir 14).

Bosetti, E.P.; Grahn, Y.; Horodyski, R.S. \& Mendlowicz Mauller, P. 2012. The first recorded decline of the Malvinokaffric Devonian fauna in the Paraná Basin (southern Brazil) and its cause; taphonomic and fossil evidences. Journal of South American Earth Sciences, 37:228-241. doi:10.1016/j.jsames.2012.02.006

Bosetti, E.P.; Grahn, Y.; Horodyski, R.S.; Mendlowicz Mauller, P.; Breuer, P. \& Zabini, C. 2011. An earliest Givetian "Lilliput Effect" in the Paraná Basin, and the collapse of the Malvinokaffric shelly fauna. Paläontologische Zeitschrift, 85:49-65. doi:10.1007/s12542-010-0075-8

Bosetti, E.P.; Horodyski, R.S.; Comniskey, J.C.; Ghilardi, R.P. \& Sedorko, D. 2014. Tubos vestimentiferos no Eogivetiano da Formação São Domingos, Bacia do Paraná. In: SIMPÓSIO BRASILEIRO DE PALEOINVERTEBRADOS, 2, 2014. Boletim de Resumos, Ponta Grossa, p. 7.

Boucot, A.J. 1971. Malvinokaffric Devonian marine community distribution and implication for Gondwana. Anais da Academia Brasileira de Ciências, 43:23-49.

Breuer, P. \& Grahn, Y. 2011. Middle Devonian spore stratigraphy in the eastern outcrop belt of the Parnaíba Basin, northeastern Brazil. Revista Española de Micropaleontologia, 43:19-38.

Carbonaro, F.A. \& Ghilardi, R.P. 2016. Fósseis do Devoniano do Estado de Goiás (Sub-bacia Alto Garças, Bacia do Paraná). Papéis Avulsos de Zoologia, 56, 135-149. doi:10.11606/00311049.2016.56.11.

Carozzi, A.V.; Falkenhein, F.U.H.; Carneiro, R.G.; Esteves, F.R. \& Contreiras, C.J.A. 1975. Análise ambiental e evolução tectônica sinsedimentar da seção Siluro-Eocarbonífera da Bacia do Maranhão. Ciência Técnica Petróleo, Seção Exploração de Petróleo, 7:1-48.

Carvalho, M.G.P.; Melo, J.H.G. \& Quadros, L.P. 1987. Trilobitas Devonianos doflanco noroeste da Bacia do Paraná. In: CONGRESSO BRASILEIRO DE PALEONTOLOGIA, 10, 1987. Anais, Rio de Janeiro, UFRJ, p. 545-565.

Castro, J. S. 1968. Trilobitas da Formação Pimenteira, Devoniano do Estado do Piauí. Anais da Academia Brasileira de Ciências, 40:481-489.

Cordani, U.G.; Neves, B.B.B.; Fuck, R.A.; Porto, R.; Thomaz-Filho, A. \& Cunha, F.M.B. 1984. Estudo preliminar de integração do Pré-Cambriano com os eventos tectônicos das bacias sedimentares brasileiras. Ciência Técnica Petróleo, Seção Exploração de Petróleo, 15:1-70.

Davies, D.J.; Powell, E.N. \& Stanton JR, R.J. 1989. Relative rates of shell dissolution and net sediment accumulation - a commentary: can shell beds form by the gradual accumulation of biogenic debris on the sea floor? Lethaia, 22:207-212.

Fonseca, V.M.M. \& Melo, J.H.G. 1987. Ocorrência de Tropidoleptus carinatus (Conrad) (Braquiopoda, Orthida) na Formação Pimenteira, e sua importância paleobiogeográfica. In: CONGRESSO BRASILEIRO DE PALEONTOLOGIA, 10, 1987. Anais, Rio de Janeiro, SBP, p. 505-537.

Francisco, A.P. \& Scheffler, S.M. 2014. Os primeiros crinoides de Goiás (Emsiano - Eifeliano) e do Givetiano do Paraná, Bacia do Paraná, Brasil. In: SIMPÓSIO BRASILEIRO DE
PALEOINVERTEBRADOS, 2, 2014. Boletim de Resumos, Ponta Grossa, p. 43-50.

Frey, R.W. \& Seilacher, A. 1980. Uniformity in marine invertebrate ichnology. Lethaia, 13:183-207.

Ghilardi, R.P.; Scheffler, S.M.; Horodyski, R.S. \& Bosetti, E.P. 2011. Ocorrência de macroinvertebrados pós-evento Kačák: Considerações prévias sobre paleobiogeografia do Eogivetiano da Bacia do Paraná. Paleontologia em Destaque, 65:30.

Grahn, Y. \& Melo, J.H.G. 2003. Silurian - Devonian chitinozoan biostratigraphy along the Urubu, Uatumã and Abacate rivers in the western part of the Amazonas Basin, northern Brazil. Bulletin of Geosciences, 78:373-391.

Grahn, Y. \& Melo, J.H.G. 2005. Devonian Chitinozoa and biostratigraphy of the Parnaíba and Jatobá basins, northeastern Brazil. Palaeontographica B, 272:1-50.

Grahn, Y.; Melo, J.H.G. \& Loboziak, S. 2006. Integrated Middle and Late Devonian miospore and chitinozoan zonation of the Parnaíba Basin, northeastern Brazil: an update. Revista Brasileira de Paleontologia, 9:283-294. doi:10.4072/rbp.2006.3.03

Grahn, Y.; Melo, J.H.G. \& Steemans, P. 2005. Integrated chitinozoan and miospore zonation of the Serra Grande Group (Silurian - lower Devonian), Parnaíba Basin, northeast Brazil. Revista Española de Micropaleontologia, 37:183-204.

Grahn, Y.; Mendlowicz Mauller, P.; Bergamaschi, S. \& Bosetti, E.P. 2013. Palynology and sequence stratigraphy of three Devonian rock units in the Apucarana Sub-basin (Paraná Basin, south Brazil): additional data and correlation. Review of Palaeobotany and Palynology, 198:27-44. doi:10.1016/j.revpalbo.2011.10.006

Grahn, Y.; Mendlowicz Mauller, P.; Breuer, P.; Bosetti, E.P.; Bergamaschi, S. \& Pereira, E. 2010a. The Furnas/Ponta Grossa contact and the age of the lowermost Ponta Grossa Formation in the Apucarana Sub-basin (Paraná Basin, Brazil): integrated palynological age determination. Revista Brasileira de Paleontologia, 13:89-102. doi:10.4072/rbp.2010.2.02

Grahn, Y.; Mendlowicz Mauller, P.; Pereira, E. \& Loboziak, S. 2010 b. Palynostratigraphy of the Chapada Group and its significance in the Devonian stratigraphy of the Paraná Basin, south Brazil. Journal of South American Earth Sciences, 29:354-370. doi:10.1016/j.jsames.2009.09.001

Grahn, Y.; Pereira, E. \& Bergamaschi, S. 2000. Silurian and Lower Devonian chitinozoan biostratigraphy of the Paraná Basin in Brazil and Paraguay. Palynology, 24:143-172. doi:10.1080/01 916122.2000.9989542

Grahn, Y.; Pereira, E. \& Bergamaschi, S. 2002. Middle and Upper Devonian chitinozoan biostratigraphy of the Paraná Basin in Brazil and Paraguay. Palynology, 26:135-165. doi:10.1080/01 916122.2002.9989570

Horodyski, R. S. 2014. Análise Tafonômica, bioestratigráfica e paleoambiental do invertebrados marinhos na região de TibagiPR (Devoniano Inferior e Médio da Bacia do Paraná). Programa de Pós-Graduação em Geociências, Universidade Federal do Rio Grande do Sul, Ph.D. thesis, 205 p.

Horodyski, R.S.; Holz, M.; Grahn, Y. \& Bosetti, E.P. 2014. Remarks on Sequence Stratigraphy and taphonomy of the Malvinokaffric shelly fauna during the KAČÁK Event in the Apucarana Subbasin (Paraná Basin), Brazil. International Journal of Earth Sciences, 103:367-380. doi:10.1007/s00531-013-0954-9

House, M.R. 1996. The Middle Devonian KAČÁK event. Proceedings of the Ussher Society, 9:79-84.

Isaacson, P.E. 1981. A Reassessment of Andean Mid-Paleozoic biogeography. In: CONGRESSO LATINO-AMERICANO DE PALEONTOLOGIA, 2, 1981. Anais, Porto Alegre, p. 75-78. 
Isaacson, P.E. 1996. Devonian biogeography and paleogeography of western Gondwana: malvinokaffric endemism, faunal migration, and organic microfossil provincialism. In: SIMPÓSIO SUL AMERICANO DO SILURO-DEVONIANO: ESTRATIGRAFIA E PALEONTOLOGIA, 1, 1996. Anais, Ponta Grossa, p. 193-218.

Isaacson, P.E. 2007. Mid-paleozoic biogeography of the central Andes: endemic faunas, immigrants, and paleogeography. In: Díaz-Martínez, P.E. \& I. Rábano (eds.) Fourth European Meeting on the Palaeontology and Stratigraphy of Latin America, Madrid, Instituto Geológico y Minero de España, p. 213-218 (Cuadernos del Museo Geominero 8).

Isaacson, P.E. \& Díaz-Martinez, E. 1994. Evolução paleogeografica del Paleozoico Medio y Superior de los Andes centrales $\left(14^{\circ}\right.$ a $18^{\circ} \mathrm{S}$ ) en Bolivia: evidencia del desplazmiento latitudinal de una cuenca de antepais. Revista Técnica de PFB, 15:265-282.

Isaacson, P.E. \& Perry, D.G. 1977. Biogeography and morphological conservatism of Tropidoleptus (Brachiopoda, Orthida) during the Devonian. Journal of Paleontology, 51:1108-1122.

Isaacson, P.E. \& Sablock, P.E. 1990. Devonian paleogeography and palaeobiogeography of the Central andes. Memoir Geological Society of London, 12:431-435. doi:10.1144/GSL. MEM.1990.012.01.40

Lieberman, B.S. 1993. Systematics and biogeography of the "Metacryphaeus Group", Calmoniidae (Trilobita, Devonian), with comments on adaptative radiations and the geological history of the Malvinokaffric Realm. Journal of Paleontology, 67:549-570. doi:10.1017/S0022336000024902

Lieberman, B.S.; Edgecombe, G.D. \& Eldredge, N. 1991. Systematics and biogeography of the "Malvinella group", Calmoniidae (Trilobita, Devonian). Journal of Paleontology, 65:824-843. doi:10.1017/S002233600003780X

Martin, K.D. 2004. A re-evaluation of the relationship between trace fossils and dysoxia. In: D. McIlroy (ed.) The application of ichnology to palaeoenvironmental and stratigraphic analysis, London, Geological Society, p. 141-156 (Special Publications 228).

Melo, J.H.G. 1988. The Malvinokaffric realm in the Devonian of Brazil. In: McMillan, N.J.; Embry, A.F. \& Glass, D.J. (eds.) Devonian of the World, Calgary, Canadian Society of Petroleum Geologists Memoires, , p. 669-703 (Memoir 14).

Melo, J.H.G. \& Loboziak. S. 2003. Devonian - Early Carboniferous miospore biostratigraphy of the Amazon Basin, Northern Brazil. Review of Palaeobotany and Palynology, 124:131-202. doi:10.1016/S0034-6667(02)00184-7

Oliveira, E.P. 1912. O terreno devoniano do sul do Brasil. Annaes da Escola de Minas de Ouro Preto, 14:31-41.

Rubinstein, C.; Melo, J.H.G. \& Steemans, P. 2005. Lochkovian (earliest Devonian) miospores from the Solimões Basin, northwestern Brazil. Review of Palaeobotany and Palynology, 133:91-113. doi:10.1016/j.revpalbo.2004.09.003

Scheffler, S.M. 2010. Crinóides e Blastóides do Devoniano Brasileiro. Programa de Pós-Graduação em Geologia, Universidade Federal do Rio de Janeiro, Ph.D. thesis, 288 p.

Scheffler, S.M.; Dias-da-Silva, S.; Gama Jr., J.M.; Da-Fonseca, V.M.M. \& Fernandes, A.C.S. 2011. Middle Devonian Crinoids from the Parnaiba Basin (Pimenteira Formation, Tocantins State, Brazil). Journal of Paleontology, 85:1188-1198. doi:10.1666/10-142.1

Speyer, S.E. \& Brett, C.E. 1986. Trilobite taphonomy and Middle Devonian taphofacies. Palaios, 1:312-327. doi:10.2307/3514694

Speyer, S.E. \& Brett, C.E. 1988. Taphofacies models for epeiric sea environments: Middle Paleozoic examples. Palaeogeography, Palaeoclimatology, Palaeoecology, 63:225262. doi:10.1016/0031-0182(88)90098-3

Received in March, 2016; accepted in August, 2016. 